\title{
PENGARUH SUBSTITUSI TEPUNG BATANG NANAS (ANANAS COMOSUS) DAN RED KIDNEY BEAN (PHASEOLUS VULGARIS) TERHADAP DAYA TERIMA, KADAR PATI RESISTEN \& PROTEIN PADA MI INSTAN
}

\author{
The Impact of Pineapple Stem Flour (Ananas Comosus) and Red Kidney Bean Substitution \\ Toward Acceptability, Resistant Starch Content and Protein on Instant Noodle \\ Yama Dharma Putera ${ }^{*}$, Annis Catur Adi ${ }^{2}$ \\ ${ }^{1}$ Program Studi S1 Gizi, Fakultas Kesehatan masyarakat, Universitas Airlangga, Surabaya, Indonesia \\ 2 Departemen Gizi ${ }^{2}$ Kesehatan, Fakultas Kesehatan Masyarakat, Universitas Airlangga, Surabaya, Indonesia \\ *E-mail: yamadharma.p@gmail.com
}

\begin{abstract}
ABSTRAK
Mi instan merupakan salah satu makanan yang digemari di Indonesia karena penyajiannya yang cepat dan mudah diterima oleh masyarakat umum. Namun, kandungan gizi dan frekuensi makan mi instan yang berlebihan menjadi salah satu penyebab terjadinya sindrom metabolik yang saat ini meningkat secara global. Penelitian ini bertujuan untuk mengetahui pengaruh substitusi tepung batang nanas dan red kidney bean (kacang jogo) pada tepung terigu terhadap daya terima, kadar pati resisten dan protein pada mi instan. Penelitian dilakukan dengan desain eksperimental murni dengan rancangan acak lengkap menggunakan formula kontrol (F0), formula substitusi F1 (tepung batang nanas 5\% dan tepung kacang jogo 20\%) dan F2 (tepung batang nanas 7\% dan tepung kacang jogo 28\%). Sebanyak 27 panelis semi terlatih dilibatkan untuk pengukuran daya terima. Hasil daya terima dianalisis dengan metode Kruskall-Wallis dan dilanjutkan Mann-Whitney jika perbedaan tampak signifikan $(\alpha \leq 0,05)$. Kadar pati resisten dan protein diukur menggunakan metode spektrofotometi dan khjeldal, kemudian hasilnya dibandingkan dengan perhitungan teoritis dari Daftar Komposisi Bahan Makanan dan beberapa penelitian. Hasil uji daya terima menyatakan bahwa formula substitusi yang paling disukai oleh panelis adalah F2 (28\% tepung kacang jogo dan 7\% tepung batang nanas). Kandungan protein dan pati resisten tertinggi terdapat pada F2 (14,4 g dan 11,3 g). Perbedaan yang signifikan terlihat antara F0 dengan F1 dan F2 pada karakteristik daya terima warna $(p=0,001)$ dan tekstur $(p=0,008)$. Konsumsi mi instan formula substitusi $28 \%$ tepung kacang jogo dan $7 \%$ tepung batang nanas dengan saran penyajian penambahan setengah butir telur dapat memenuhi porsi konsumsi rekomendasi sekali makan pati resisten dan protein yang dapat mencegah terjadinya sindrom metabolik.
\end{abstract}

Kata kunci: batang nanas, mi instan, pati resisten, protein, red kidney bean

\section{ABSTRACT}

Instant noodle is one of the most popular food in Indonesia because of the fast preparation and easily accepted by people.. However, the nutritional content and overeating instant noodle, become one of the causes metabolic syndrome which is currently increasing globally. This study was aimed to determine the effect of pineapple stem starch flour and red kidney bean (jogo bean) flour substitution on wheat flour towards acceptability, levels of resistant starch and protein in instant noodle. The research was done by using a true experimental with a randomized design consisted of the control formula (F0), F1 substitution formula (5\% pineapple stem flour and 20\% jogo bean flour) and F2 (7\% pineapple stem flour and 28\% jogo bean flour). A total of 27 person were involved as semi-trained panelists, acceptance level was tested by Kruskall-Wallis and continued by the Mann-Whitney if the difference appeared significant ( $\alpha \leq 0.05)$. Resistant starch and protein content will be compared between theoretical calculations from Indonesia Food database and some research with laboratory tests. Acceptance test results state that the most favored substitution formula by panelists is F2 (28\% jogo bean flour and 7\% pineapple stem flour). The highest protein content and resistant starch was found in F2 (14.4 g and $11.3 \mathrm{~g}$ ). Significant differences were seen between F0 with F1 and F2 in the characteristics of color acceptability $(p=0.001)$ and texture $(p=0.008)$. Consumption of instant noodles substitution formula F2 with adding a half egg can meet the recommended consumption of one meal of resistant starch and protein which has benefits in preventing the metabolic syndrome.

Keywords: Instant noodle, Pineapple stem, Protein, red kidney bean, resistant starch. 


\section{PENDAHULUAN}

Mi instan merupakan produk makanan yang sangat digemari di Indonesia. Banyaknya varian rasa, gencarnya iklan, mudah dan cepat untuk disajikan, terjangkau serta murah menjadi keunggulan mi instan (Nurcahyo, 2011). Secara global Indonesia menempati peringkat kedua setelah Tiongkok dalam permintaan terhadap produk mi instan yang mencapai 12.540 juta porsi (WINA, 2019)

Konsumsi mi instan dapat menyebabkan asupan energi (Park et al., 2011) dipicu oleh tingginya muatan glikemiks karbohidrat sederhana yang berasal dari tepung terigu (Kim et al., 2000). Menurut Huh et al. (2017), seseorang pada usia produktif yang memiliki frekuensi konsumsi mi instan $\geq 3$ kali dalam seminggu lebih rentan terkena hipertrigliseridemia, obesitas abdominal, dan hiperglikemia masing-masing sebesar 2,6; 1,6 dan 1,3 kali. Jawa Timur merupakan provinsi dengan proporsi penduduk usia $\geq 10$ tahun yang mengonsumsi mi instan lebih dari 1 kali per hari sebesar 6,7\% (Kementerian Kesehatan RI, 2013). Kandungan energi yang berlebih dan frekuensi konsumsi mi instan yang sering ( $\geq 2$ kali dalam seminggu) berkontribusi terhadap peningkatan risiko sindrom metabolik terhadap seseorang sebanyak 68\% (Shin et al., 2014).

Prevalensi sindrom metabolik di Indonesia mulai meningkat seiring dengan waktu. Jawa Timur merupakan provinsi yang memiliki prevalensi sindrom metabolik melebihi angka nasional (21,66\%) dengan angka 23,59\% (Herningtyas \& Ng, 2019). Berdasarkan Badan Penelitian dan Pengembangan Kesehatan (2018), memaparkan beberapa kondisi terkait sindrom metabolik, proporsi obesitas sentral pada dewasa $\geq$ 15 tahun meningkat menjadi 30,38\% dengan angka sebelumnya $24,3 \%$, prevalensi diabetes melitus meningkat menjadi 2,6 dari 2,1 (Kementerian Kesehatan RI, 2013). Angka mortalitas terhadap kondisi kesehatan terkait sindrom metabolik menjadi penyebab utama dari penyakit tidak menular lainnya (WHO, 2018). Dengan dampak yang besar, prevalensi penyakit terus meningkat dan didukung oleh perilaku yang berisiko (konsumsi mi yang tinggi), maka diperlukan penelitian dengan tujuan meningkatkan kualitas nutrisi atau membuat mi instan yang lebih sehat.
Penelitian mi yang mengarah pada peningkatan gizi berbasis tepung dengan meningkatkan karbohidrat yang kompleks telah dilakukan untuk menciptakan mi dengan kandungan kalori dan indeks glikemik yang lebih rendah dengan tujuan menghindari sindrom metabolik (Arora et al., 2018; Noda et al., 2006; Olorunsogo et al., 2019; Pato et al., 2019; Sirichokworrakit et al., 2015). Pati resisten merupakan salah satu golongan karbohidrat kompleks yang mampu mencegah beberapa risiko sindrom metabolik (Aller et al., 2011).

Tepung batang nanas merupakan bahan potensial pembentuk pati resisten. Selama ini, batang nanas belum pernah dimanfaatkan dan hanya menjadi limbah untuk dibakar ketika musim tanam nanas tiba. Jawa Timur merupakan daerah keempat terbesar penghasil nanas (158.407 ton/ tahun) di Indonesia (Pusdatin, 2016). Potensi yang dimiliki oleh batang nanas adalah kadar amilosanya yang cukup tinggi mencapai 35\% (Nakthong et al., 2017), semakin tinggi kadar amilosa maka semakin banyak pula pati resisten yang dapat dihasilkan (Dupuis et al., 2014).

Selain menggunakan tepung batang nanas, untuk menambah nilai dan kualitas kandungan gizi pada mi instan, maka dikombinasikan dengan red kidney bean. Red kidney bean atau yang lebih dikenal dengan kacang jogo merupakan tanaman asli Amerika yang telah banyak ditanam di daerah dengan ketinggian $1.400 \mathrm{~m}$ hingga 2.000 $\mathrm{m}$ diatas permukaan laut. Kota Batu (Malang), Pulau Lombok, Lembang (Bandung), dan Pacet (Cipanas) merupakan daerah penghasil kacang jogo di Indonesia (Astawan, 2011). Bahan tambahan ini memiliki 9-11\% pati resisten (Du et al., 2014; Sasanam et al., 2011). Selain itu, kandungan protein pada red kidney bean mencapai 20-24\% (Huma et al., 2008; Olanipekun et al., 2015). Protein juga memiliki efek mempertahankan tingkat kekenyangan yang lebih lama (Paddonjones et al., 2008). Kandungan indeks glikemik serta kalori yang rendah pada red kidney bean (Foster-Powell \& Miller, 1995) juga membantu pencegahan terjadinya sindrom metabolik.

Penelitian produk makanan berupa roti dengan substitusi tepung kacang jogo telah dilakukan sebelumnya (Manonmani et al., 2014). Hasil penelitian menyatakan bahwa roti yang disubstitusi 
kacang jogo 15\% memiliki karakteristik tekstur dan penilaian organoleptik yang dapat diterima. Penelitian terkait batang nanas yang digunakan sebagai produk formulasi makanan belum pernah dilakukan, namun menurut Office of the Gene Technology Regulator (2003), batang nanas aman untuk dikonsumsi karena strukturnya sama dengan peduncle (batang yang terdapat pada bagian dalam buah nanas) yaitu sedikit keras dan dapat dijadikan sumber serat yang baik.

Berdasarkan keunggulan antara kedua bahan yang telah dipaparkan, maka penelitian ini bertujuan untuk mengetahui pengaruh tepung batang nanas dan kacang jogo terhadap daya terima yang dinilai layak dan berkualitas dilihat dari hasil uji organoleptik dan nilai gizi (pati resisten dan protein) sebagai produk mi instan yang lebih sehat.

\section{METODE}

Penelitian ini merupakan jenis penelitian eksperimental murni dengan desain Rancangan Acak Lengkap (RAL) yang terdiri dari 3 perlakuan dan 6 kali pengulangan. Penelitian ini telah lolos kajian etik oleh Komisi Etik Fakultas Keperawatan Universitas Airlangga, Surabaya dengan sertifikat etik No: 1865-KEPK tanggal 23 Desember 2019.

Substitusi yang dilakukan yaitu menggantikan sebagian tepung terigu dengan tepung batang nanas (\%) dan tepung red kidney bean (\%). Persentase substitusi tepung batang nanas dan red kidney bean terhadap terigu disajikan pada Tabel 1.

Peneliti telah melakukan penelitian pendahuluan untuk mengetahui persentase substitusi dengan tujuan untuk mencapai zat gizi yang diperlukan (protein dan pati resisten) dan mendapatkan karakteristik mi yang sama seperti di pasaran. Berdasarkan hasil penelitian

Tabel 1. Formulasi Mi Instan Tepung Batang Nanas dan Tepung Red Kidney Bean

\begin{tabular}{lccc}
\hline \multirow{2}{*}{ Formula } & $\begin{array}{c}\text { Tepung } \\
\text { Terigu }\end{array}$ & $\begin{array}{c}\text { Tepung } \\
\text { Batang } \\
\text { Nanas }\end{array}$ & $\begin{array}{c}\text { Tepung Red } \\
\text { Kidney Bean }\end{array}$ \\
\hline F0 & $100 \%$ & $0 \%$ & $0 \%$ \\
F1 & $75 \%$ & $5 \%$ & $20 \%$ \\
F2 & $65 \%$ & $7 \%$ & $28 \%$ \\
\hline
\end{tabular}

pendahuluan tersebut, diperoleh persentase substitusi tepung batang nanas $5 \%$ dan kacang jogo $20 \%$. Nilai tersebut paling sesuai untuk mendekati protein sebesar 20 gram dan pati resisten 6,5 gram untuk tiap sajian produk mie dengan tujuan mencapai manfaat potensial dalam menurunkan risiko sindrom metabolik (Moore et al., 2009; Symons et al., 2009; Behall et al., 2006). Pada penelitian pendahuluan, dua formula substitusi (F1 dan F2) telah melalui uji daya terima yang melibatkan 6 panelis terbatas untuk mengevaluasi serta mendapatkan karakteristik mi yang sama seperti mi pada umumnya yaitu bertekstur kenyal, tidak terlalu berair, tidak mudah patah, berwarna kuning dan memiliki aroma khas minyak (Hou, 2010)

Tahapan penelitian dibagi menjadi 4 tahap: (1) persiapan tepung batang nanas dan kacang jogo; (2) pembuatan produk mie instan; (3) pengujian organoleptik; (4) analisis kadar protein dan pati resisten pada formula terbaik. Pembuatan tepung batang nanas dengan pembentukan pati resisten secara fisik menelaah pada metode yang dilakukan oleh Wulan et al. (2006), yang dimodifikasi. Langkah-langkah pembuatannya adalah, pertama mengupas kulit dari batang nanas agar tepung yang dihasilkan berwana putih, kemudian potong dengan ketebalan $1 \mathrm{~cm}$. Selanjutnya, rebus pada panci bertekanan dengan suhu $121^{\circ} \mathrm{C}$ selama 15 menit, dinginkan pada suhu $4^{\circ} \mathrm{C}$ selama $12 \mathrm{jam}$, keluarkan dari pendingin dan diamkan 1 jam, lalu dikeringkan pada sinar matahari selama 6 jam. Setelah didapatkan batang nanas yang kering, giling menggunakan food processor dan diayak dengan ukuran 200 mesh.

Penepungan kacang jogo mengacu pada metode yang diterapkan oleh Pangastuti et al., (2013) yang dimodifikasi. Proses awal dimulai dari perendaman selama 24 jam dan perebusan selama 90 menit dengan perbandingan 1:10 dengan air. Selanjutnya dikeringkan dalam oven bersuhu $50^{\circ} \mathrm{C}$ hingga kadar air mencapai 6-6,5\% menggunakan moisture tester. Tahap akhir dari proses ini adalah penepungan dan pengayakan.

Resep pembuatan mi diperoleh dari penelitian Rosida (2012) yang dimodifikasi. Pembuatan adonan mi instan substitusi pertama dengan mencampurkan semua bahan seperti telur (27 $\mathrm{g})$, tepung terigu, air $(10 \mathrm{~g})$, garam $(1 \mathrm{~g})$, tepung 
batang nanas dan tepung kacang jogo. Jumlah pencampuran bahan substitusi menyesuaikan dengan persentase pada tabel 1. Kemudian semua bahan diaduk dengan alat bantu atau pengulenan. Aduk adonan selama 15-25 menit. Kemudian mi dipipihkan menggunakan alat roll-press untuk pembentukan lembaran serta menghaluskan seratserat gluten hingga ketipisan di angka 8, diulang lagi proses tersebut hingga mencapai ketebalan mi yang diinginkan. Selanjutnya mi di potong pada proses pengirisan memanjang (slitting), sehingga menjadi tali berbentuk senar. Kemudian, kukus mi selama 10 menit untuk mematangkannya kemudian digoreng dengan metode deep fat frying pada suhu $140-160^{\circ} \mathrm{C}$ selama 2 menit dan tiriskan mi.

Pengumpulan data daya terima (warna, aroma, tekstur dan rasa) diperoleh melalui uji hedonik (uji kesukaan) merujuk pada Meilgaard (2015), dengan penilaian tingkat kesukaan (sangat tidak suka $=1$, kurang suka $=2$, netral $=3$, suka $=4$ dan sangat suka $=5$ ). Sampel mi instan yang berjumlah 12,5 gram yang dihidangkan setelah direbus sebelumnya pada masing-masing formula dinilai oleh panelis semi terlatih yang merupakan anggota Klub Organoleptik Gizi Universitas Airlangga sebanyak 27 orang. Tiap pengujian daya terima masing-masing formula, panelis akan menetralkan mulut dengan menggunakan air putih untuk menghindarkan bias penilaian organoleptik antar formula. Analisis terhadap uji hedonik dilakukan dengan menggunakan uji Kruskall-Wallis. Apabila terdapat perbedaan daya terima yang signifikan, dilanjutkan dengan uji Mann Whitney.

Uji laboratorium dilakukan untuk mengukur kandungan protein dan pati resisten menggunakan metode kjeldahl (AOAC, 2005) dan spektrofotometri (Dubois et al., 1956) yang dilakukan terhadap formula mi instan substitusi yang memiliki daya terima terbaik. Uji laboratorium dilakukan di laboratorium biokimia dan analisis gizi Fakultas Kesehatan Masyarakat Universitas Airlangga.

\section{HASIL DAN PEMBAHASAN}

Penilaian daya terima dilakukan dengan menggunakan uji kesukaan yang meliputi penilaian warna, tekstur, aroma dan rasa. Penilaian dengan uji kesukaan terhadap warna, rasa, aroma dan tekstur yang dapat dilihat pada Tabel 2 .

\section{Warna}

Hasil uji daya terima terkait warna secara kuantitatif dengan tingkat kesukaan tertinggi hingga terendah menyatakan bahwa warna formula kontrol (F0) disukai oleh panelis dan diikuti oleh formula substitusi F2 dan F1 dengan kategori netral. Warna dari F0 sangat biasa atau umum dijumpai pada mi instan komersial dengan warna kuning pucat, sedangkan pada formula substitusi F1 dan F2 warnanya cenderung merah kecoklatan, gelap dan pucat.

Hasil analisis statistik menggunakan metode Kruskal-Walis menyatakan bahwa terdapat perbedaan warna yang signifikan antara F0, F1 dan F2, kemudian dianalisis lebih lanjut menggunakan metode Mann whitney yang menghasilkan adanya beda signifikan antara warna formula kontrol (F0) dengan formula substitusi F1 $(p=0,009)$ dan F2 $(p=0,000)$, namun untuk kedua formula substitusi tidak memiliki perbedaan warna yang signifikan.

Hasil uji penerimaan warna yang berbeda ini dapat disebabkan oleh proses pengolahan pangan yang melibatkan panas. Pigmen alami dari kacang jogo yang terdapat pada formula substitusi akan mengalami degradasi dan proses nonenzimatic browning (NEB) ketika terjadi proses pemanasan dengan suhu $100-180^{\circ} \mathrm{C}$ (Jiménez et al., 2010). Terdegradasinya antosianin akan memudarkan warna merah yang ada dan terjadinya proses NEB/ reaksi maillard akan memunculkan warna kecoklatan pada mi substitusi (Dutson \& Orcutt, 1984). Penilaian warna tertinggi pada F0 disebabkan oleh tidak adanya antosianin dari kacang jogo sehingga warna kuning pucat hingga cerah tampak. Persepsi masyarakat umum masih menganggap warna kuning dan kecerahannya

Tabel 2. Rata-rata Tingkat Kesukaan Panelis terhadap Daya Terima Mi Instan

\begin{tabular}{lllll}
\hline \multirow{2}{*}{ Karakteristik } & \multicolumn{2}{l}{ Formula } & p-value \\
\cline { 2 - 5 } & F0 & F1 & F2 & \\
\hline Aroma & $3,8^{\mathrm{c}}$ & $3,5^{\mathrm{c}}$ & $3,7^{\mathrm{c}}$ & 0,276 \\
Warna & $4^{\mathrm{a}}$ & $3,3^{\mathrm{b}}$ & $3,1^{\mathrm{b}}$ & $0,001^{*}$ \\
Rasa & $3,9^{\mathrm{d}}$ & $3,6^{\mathrm{d}}$ & $3,8^{\mathrm{d}}$ & 0,414 \\
Tekstur & $4,2^{\mathrm{a}}$ & $3,3^{\mathrm{b}}$ & $3,5^{\mathrm{b}}$ & 0,008 \\
Rata-rata & 4,0 & 3,4 & 3,5 & \\
\hline
\end{tabular}

Keterangan : Angka yang diikuti dengan huruf yang berbeda pada baris yang sama menunjukkan adanya perbedaan nyata 
merupakan penampilan mi yang terbaik (Hou, 2010).

Hasil ini sama dengan penelitian Aliya et al. (2016), mi instan dengan warna yang semakin cokelat gelap memiliki daya terima yang semakin menurun. Walaupun terjadi penurunan nilai tingkat penerimaan warna, namun tingkat penerimaan masih pada batas penilaian yang baik yaitu netral sekalipun pada formula substitusi tertinggi (F2).

\section{Aroma}

Aroma mi instan yang melalui proses deep fat frying sangat ditentukan oleh kualitas minyak yang digunakan untuk menggorengnya. Aroma mi instan yang baik adalah setelah disimpan selama 15-30 jam tidak menimbulkan bau tengik (Hou, 2010). Persyaratan aroma mi instan yang ditetapkan oleh Badan Standardisasi Nasional (2012), berdasarkan SNI 3551:2012 yaitu memenuhi kategori "Normal" yang bisa diartikan sebagai aroma yang dapat diterima oleh masyarakat umum.

Aroma formula kontrol (F0) memiliki aroma yang sangat mirip dengan mi instan komersial, yaitu harum aroma minyak. Sedangkan pada formula substitusi (F1 dan F2) memiliki aroma yang tidak jauh berbeda dengan formula kontrol. Pada proses deep fat frying, aroma makanan akan cenderung berubah dikarenakan reaksi antara panas dan minyak dengan zat gizi yang terkandung pada makanan tersebut. Proses oksidasi minyak akan terjadi selama deep fat frying berlangsung, dalam proses tersebut akan melepas gugus-gugus minyak dan menghasilkan senyawa aldehid, ester, alkohol, komponen aromatik, gliserol, asam lemak bebas yang dapat mempengaruhi rasa dan aroma produk (Gillatt, 2001).

Hasil uji statistik menyatakan, interaksi antara aroma formula substitusi (F1 dan F2) dan formula kontrol tidak memiliki perbedaan yang signifikan $(p=0.276)$. Berdasarkan hasil statistik yang tidak memiliki perbedaan dalam penerimaan aroma, maka dapat dilihat bahwa aroma dari formula subtitusi (F1 dan F2) dapat diterima sebaik formula kontrol (F0) dengan nilai rerata kategori diantara netral dan suka.

\section{Rasa}

Peranan rasa terbaik yang timbul merupakan komponen penting yang tidak terpisahkan dengan aroma demi mencapai rasa puas/ kenyang yang lebih berkualitas setelah memakan makanan tertentu (Yin et al., 2017). Persyaratan rasa mi instan yang ditetapkan oleh Badan Standardisasi Nasional (2012), berdasarkan SNI 3551:2012 yaitu memenuhi kategori "Normal" yang bisa diartikan sebagai rasa yang dapat diterima oleh masyarakat umum.

Formula kontrol (F0) memiliki rasa yang cenderung netral (tidak asin dan manis). Pada formula substitusi (F1 dan F2) rasa yang timbul cenderung gurih dan ada aftertaste agak pahit. Hal ini dapat disebabkan oleh kandungan asam amino glutamin dan asam glutamat (Margier et $a l ., 2018)$ yang ada pada kacang jogo yang dapat menimbulkan rasa gurih pada makanan serta dipengaruhi pula oleh jumlah kacang jogo semakin meningkat pada dari F1 hingga F2.

Aftertaste agak pahit pada formulasi substitusi (F1 dan F2) muncul akibat kandungan zat tanin yang masih tersisa pada olahan kacang jogo (Kumar et al., 2013). Tanin pada kacang jogo merupakan salah satu bentuk polifenol yang dapat berfungsi sebagai antioksidan dan antiinflamasi dengan beberapa manfaatnya dapat mencegah kanker (antikarsinogenik), penuaan dan diabetes pada tubuh (Margier et al., 2018; Singh et al., 2017). Pada saat yang sama, tanin juga disebut sebagai zat antinutrisi karena kemampuannya yang dapat mengurangi penyerapan zat besi dan protein pada tubuh (Karamać, 2009). Meskipun demikian, konsumsi tanin dinyatakan aman dan tidak berbahaya bagi tubuh, tanin akan terdegradasi oleh bakteri atau enzim dalam usus dan hasilnya dapat diserap (European Food Safety Authority, 2014).

Perbedaan rasa yang muncul pada formula kontrol (F0) dan substitusi (F1 dan F2) berdasarkan uji statistik, tidak memiliki perbedaan yang signifikan $(p=0,414)$. maka, dapat disimpulkan bahwa substitusi yang dilakukan pada F1 (tepung batang nanas 5\% dan tepung kacang jogo 20\%) dan F2 (tepung batang nanas 7\% dan tepung kacang jogo $28 \%$ ) tidak memiliki dampak berarti terhadap rasa dibandingkan dengan mi instan biasa (F0). Berpijak dengan hasil statistik yang tidak memiliki perbedaan dalam penerimaan rasa, dapat dilihat bahwa rasa dari formula substitusi (F1 dan F2) dapat diterima sebaik formula kontrol (F0) dengan nilai rerata kategori diantara netral dan suka. 


\section{Tekstur}

Persyaratan tekstur mi Badan Standardisasi Nasional (2012), sangatlah umum yaitu "Normal" yang bisa diartikan sebagai tekstur yang dapat diterima oleh masyarakat umum, sedangkan menurut Hou (2010), masyarakat Indonesia lebih menyukai mi dengan tekstur permukaan yang lebih keras dan kenyal dibandingkan dengan orang Jepang yang lebih menyukai mi dengan tekstur lembut dan elastis.

Berdasarkan analisis statistik, mi instan yang memiliki tingkat kesukaan tekstur dengan ratarata tertinggi adalah F0 $(4,2)$, sedangkan F1 dan F2 memperoleh rata-rata yang tidak berbeda jauh yaitu 3,3 dan 3,5. Formula kontrol (F0) memiliki tekstur yang sangat kenyal dan padat, sedangkan formula substitusi F1 dan F2 memiliki karakteristik tekstur yang kenyal dan lembut.

Perbedaan tekstur yang dirasakan yaitu tingkat kekenyalan yang cenderung menurun dikarenakan penurunan gluten yang terbentuk akibat dari substitusi tepung terigu yang meningkat pada formula substitusi F1 terendah dan F2 tertinggi. Jaringan gluten terbentuk pada saat protein dari tepung terigu menyerap air dalam proses pencampuran adonan mi, melengketkan seluruh komponen tepung terigu menjadi satu adonan. Fungsi gluten adalah mencegah komponen yang terdapat pada adonan mi keluar dari adonan ketika dimasak dan memberikan dukungan struktural dan berkontribusi pada sifat tekstur (kekenyalan) $\mathrm{mi}$ yang dimasak (Hou, 2010).

Penggantian peran protein pada tepung terigu dengan red kidney bean yang juga memiliki protein tinggi tidak cukup menghasilkan kekenyalan yang sama seperti yang dihasilkan oleh gluten. $\mathrm{Hal}$ ini dibuktikan dengan hasil analisis statistik pada masing-masing formula menyatakan bahwa terdapat perbedaan yang signifikan antara tekstur formula kontrol ( $\mathrm{F} 0$ ) dengan formula substitusi $\mathrm{F} 1$ $(p=0,006)$ dan $\mathrm{F} 2(\mathrm{p}=0,009)$.

Meskipun, berdasarkan uji statistik antara formula kontrol dengan formula substitusi memiliki perbedaan tekstur yang signifikan, namun rerata daya terima formula substitusi masih memiliki daya terima yang cukup baik.

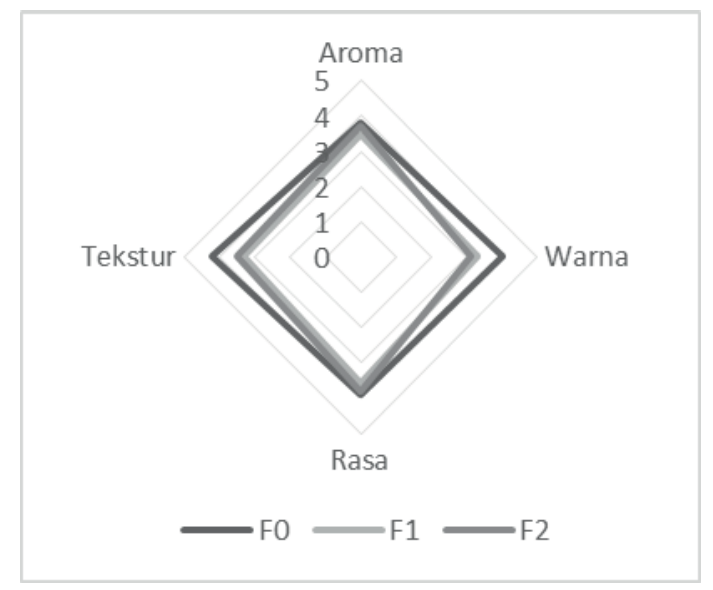

Gambar 1. Grafik Radar Tingkat Kesukaan Panelis terhadap Mi Instan

\section{Penilaian Daya Terima Terhadap Formula Mi Instan}

Penilaian daya terima tingkat kesukaan mi instan secara umum merupakan gabungan antara warna, aroma, tekstur dan rasa mi instan pada panelis yang kemudian dirata-rata. Penilaian keseluruhan panelis terhadap tingkat kesukaan mi instan dapat dilihat pada grafik radar Gambar 1.

Skala penilaian pada Gambar 1 mengikuti pada skala penilaian standar daya terima (sangat tidak suka $=1$, kurang suka $=2$, netral $=3$, suka $=4$ dan sangat suka $=5$ ). Formula kontrol (F0) memiliki penilaian tertinggi pada seluruh karakteristik uji kesukaan dengan nilai 4,0 dan dapat dilihat pada gambar 1 untuk persebaran warna, tekstur, aroma serta rasa yang mendekati kategori penilaian suka. Pada formula substitusi, yang mendekati penilaian tertinggi adalah F2 dengan nilai 3,5 dan diikuti oleh F1 dengan nilai 3,4. Formula substitusi terbaik pada penilaian daya terima adalah F2. Meskipun secara statistik F2 dan F1 tidak memiliki perbedaan yang signifikan, namun berdasarkan nilai rata-rata daya terima F2 lebih disukai daripada F1.

\section{Protein}

Analisis kandungan protein mi instan yang dilakukan dengan perhitungan teoritis dari Daftar Komposisi Bahan Makanan (DKBM) dan penelitian terkait dan uji laboratorium dapat 
dilihat pada Tabel 3. Penelitian terkait diambil dari Nakthong et al. (2017), dengan penelitian terkait limbah nanas, peneliti mengutip protein dari tepung batang nanas sebagai dasar perhitungan teoritis; penelitian Olanipekun et al. (2015), digunakan sebagai dasar perhitungan teoritis protein kacang jogo; dan Berdasarkan mi instan formula substitusi terbaik yaitu F2, kandungan protein hasil analisis laboratorium mencapai 14,4 gram. Hal ini memiliki nilai perbedaan yang lebih sedikit dengan perhitungan berdasarkan penelitian terkait dan DKBM yaitu 17,6 gram.

Penurunan protein diawali dengan denaturasi protein. Denaturasi protein terjadi ketika hidrogen dan ikatan non kovalen lainnya seperti ionik dan ikatan van der Waals pada protein terganggu oleh panas sehingga, terbentuk gugus amin bebas. Gugus amin bebas cenderung tidak stabil dan berikatan dengan gugus karbonil menjadi suatu komponen baru yang sulit untuk dicerna tubuh yang diberlangsung melalui reaksi maillard (Teodorowicz et al., 2017). Pada mi instan penurunan kadar protein akibat dari proses pemanasan disebabkan dua fase pengolahan, pertama ketika mengukus mi hingga matang dan kedua adalah ketika proses penggorengan atau deep fat frying pada suhu $140-160^{\circ} \mathrm{C}$ selama 2 menit.

Kandungan protein pada mi instan substitusi $28 \%$ tepung batang nanas dan $7 \%$ tepung red kidney bean juga telah memenuhi SNI 3551:2012 dengan standar minimal 8 gram per 100 gram, yaitu sebesar 11,2 gram. Berdasarkan hasil pengamatan, kandungan protein pada mi instan substitusi terbaik (14,4 gram) mampu mengungguli mi instan komersial yang beredar di pasaran yang hanya mencapai 10,4 gram per 130 gram sajian mi.
Rekomendasi porsi konsumsi protein sekali makan yang dikemukakan oleh Moore et al. (2009) serta Symons et al. (2009), konsumsi minimal 20 gram akan mendapatkan manfaat optimal seperti memperpanjang rasa kenyang dan kontrol terhadap berat badan yang penting untuk mencegah terjadinya sindrom metabolik. Pemenuhan rekomendasi porsi konsumsi sekali makan dapat dilihat pada tabel 4. Dengan pemenuhan sebesar $73 \%$, maka konsumsi per sajian mi instan substitusi $28 \%$ tepung batang nanas dan $7 \%$ tepung red kidney bean telah mendekati pemenuhan porsi konsumsi rekomendasi sekali makan protein. Saran penyajian dengan penambahan telur dapat memenuhi rekomendasi, karena setengah butir telur mengandung \pm 6 gram protein.

\section{Pati Resisten}

Kandungan pati resisten pada formula substitusi terbaik sejumlah 11,3 gram per porsi (130 gram) menurut hasil perhitungan analisis laboratorium. Berbeda dengan hasil perhitungan teoritis yakni 3,3 gram. Perhitungan teoritis mengacu pada penelitian Sasanam et al., (2011), digunakan sebagai dasar perhitungan teoritis pati resisten pada kacang jogo, sedangkan kandungan pati resisten pada tepung batang nanas diperoleh

Tabel 4. Pemenuhan Gizi Mi Instan Substitusi per Porsi

\begin{tabular}{lcc}
\hline Zat Gizi & $\begin{array}{c}\text { Rekomendasi Porsi } \\
\text { Konsumsi Sekali } \\
\text { Makan (g) }\end{array}$ & $\begin{array}{c}\text { Pemenuhan } \\
\text { Rekomendasi Porsi } \\
\text { Konsumsi Sekali } \\
\text { Makan (\%) }\end{array}$ \\
\hline Protein & $20-30^{1}$ & 73 \\
Pati Resisten & $6,5^{2}$ & 173 \\
\hline
\end{tabular}

${ }^{1}$ Moore et al. (2009); Symons et al. (2009)

${ }^{2}$ Behall et al. (2006)

Tabel 3. Kandungan Gizi Mi Instan Substitusi 28\% Tepung Batang Nanas dan 7\% Tepung Red Kidney Bean

\begin{tabular}{lcccc}
\hline \multicolumn{1}{c}{ Hasil } & & \multicolumn{2}{c}{ Zat Gizi } & \multicolumn{2}{c}{ SNI 3551:2012 } \\
\cline { 3 - 5 } & & Protein (g) & Pati Resisten (g) & Protein (g) ${ }^{\mathbf{1}}$ \\
\hline Perhitungan DKBM dan penelitian terkait ${ }^{2}$ & Per 100 g & 13 & 2,5 & Min. 8 \\
\multirow{2}{*}{ Uji Laboratorium } & Per 130 g (per porsi) & 17,6 & 3,3 & - \\
& Per 100 g & 11,2 & 8,7 & Min. 8 \\
\hline
\end{tabular}

${ }^{1}$ Badan Standarisasi Nasional, 2012

${ }^{2}$ Nakthong et al., 2017; Olanipekun et al., 2015; Sasanam et al., 2011 
dengan uji laboratorium yang dilakukan oleh peneliti pada penelitian pendahuluan.

Perbedaan yang cenderung meningkat sebesar 29\% dapat terjadi karena berkaitan dengan proses pembentukan pati resisten tipe III yang dapat dilakukan dengan cara fisik (Kaur et al., 2012). Adapun cara fisik yang dilakukan menurut Shamai et al. (2003), yaitu proses gelatinisasi dan retrogradasi dalam proses pengolahan makanan dapat meningkatkan jumlah pati resisten yang terdapat dalam bahan makanan. Temuan ini sama dengan yang dilakukan oleh Ashwar et al. (2016), dengan menggunakan siklus pemanasan dan pendinginan yang diulang dua kali akan meningkatkan kandungan pati resisten tipe III rata-rata $27 \%$. Pelibatan siklus gelatinisasi dan retrogradasi pada mi instan substitusi terjadi pada proses pengukusan, penggorengan serta penyimpanan pada lemari pendingin.

Peningkatan pati resisten tipe III juga didukung oleh kadar amilosa yang terkandung pada bahan makanan. Semakin tinggi kadar amilosa maka semakin banyak pati resisten yang dapat dihasilkan melalui proses pembentukan pati resisiten tipe III (Dupuis et al., 2014). Pernyataan ini juga didukung oleh penelitian yang telah dilakukan sebelumnya yaitu Wulan et al. (2006), bahwa kadar pati resisten tertinggi dihasilkan oleh jagung dengan amilosa terbanyak (19,57\%) dibandingkan dengan kentang $(7,05 \%)$ dan singkong $(7,02 \%)$ setelah melalui proses modifikasi. Batang nanas memiliki kadar amilosa sebesar $35 \%$ (Nakthong et al., 2017) dan kacang jogo 20,14\% (Ratnawati et al., 2019).

Tepung terigu juga mengalami peningkatan pati resisten dalam proses pembuatan mi. Pati resisten awal tepung terigu sebesar 0,26 per 100 gram dan dapat meningkat sebesar 1,4 kali menjadi 0,34 per 100 gram, namun peningkatan yang terjadi sangat kecil dan tidak mencapai $1 \%$ (Dhital et al., 2010). Peneliti (Dhital et al., 2010) menghubungkan peningkatan pati resisten yang sangat kecil pada tepung terigu dengan kandungan amilosa yang rendah, meskipun tidak dijelaskan berapa kadarnya. Secara perhitungan, pati resisten pada tepung terigu tidak memiliki peran yang signifikan dalam peningkatan pati resisten pada mi instan substitusi sehingga keberadaannya dapat diabaikan. Maka, peningkatan pati resisten pada formula mi substitusi utamanya dipengaruhi oleh dua bahan penyusunnya yaitu tepung batang nanas dan tepung kacang jogo.

Berdasarkan rekomendasi konsumsi pati resisten untuk mencapai fungsi fisiologis optimalnya, diperlukan sebesar $30 \mathrm{~g} /$ hari untuk laki-laki dan $25 \mathrm{~g}$ /hari untuk perempuan (Colyer et al., 2013). Pada level konsumsi yang kecil, sesuai porsi konsumsi rekomendasi sekali makan sebesar 6,5 gram, pati resisten memiliki manfaat dalam membantu memperbaiki metabolisme glukosa dengan cara menurunkan kadar glukosa posprandial dan respons insulin tubuh pada wanita normal dan wanita dengan berat badan berlebih (Behall et al., 2006). Sementara konsumsi sebesar 2,5-5 g/hari dapat menunjukkan efek prebiotik pada tubuh (Anadón et al., 2016). Maka dapat disimpulkan bahwa pemenuhan rekomendasi porsi konsumsi sekali makan pati resisten yang mencapai $173 \%$ (11,3 g) pada tabel 3 masih pada batas wajar pemenuhan kebutuhan harian pati resisten (25-30 g).

Penelitian ini masih memiliki kelemahan yaitu uji laboratorium untuk protein dan pati resisten hanya dilakukan kepada 1 formula, yaitu formula substitusi terbaik F2 berdasarkan daya terima dan nilai gizi secara perhitungan teoritis, sehingga tidak dapat dibandingkan kandungan protein dan pati resisten pada F2 dengan kontrol.

\section{KESIMPULAN}

Formula substitusi yang memiliki penilaian tertinggi (rasa, aroma, tekstur) terdapat pada formula substitusi terbaik dengan komposisi $28 \%$ tepung red kidney bean dan $7 \%$ tepung batang nanas. Berdasarkan standar mi instan SNI 3551:2012, formula substitusi terbaik telah memenuhi syarat pada bagian sensori (aroma, warna, tekstur dan rasa) serta kandungan protein minimal. Kandungan pati resisten dan protein tertinggi terdapat pada mi instan substitusi terbaik, dengan angka masing-masing 11,3 gram dan 14,4 gram.

\section{SARAN}

Konsumsi protein dan pati resisten pada level tertentu telah terbukti mampu mencegah penyebab terjadinya sindrom metabolik secara teoritis. Namun, belum ada data nyata terkait 
konsumsi mi instan substitusi tepung batang nanas $7 \%$ dan tepung kacang jogo $28 \%$ per porsi dengan saran penyajian penambahan 1 butir telur yang mampu memenuhi protein dan pati resisten untuk mencegah penyakit sindrom metabolik. Maka dari itu, penelitian ini dapat menjadi dasar untuk melakukan penelitian selanjutnya dengan berfokus pada hubungan konsumsi mi instan substitusi tepung batang nanas $7 \%$ dan tepung kacang jogo $28 \%$ dengan kejadian sindrom metabolik.

\section{DAFTAR PUSTAKA}

AOAC. (2005). Official method of analysis of the association of official analytical chemist. Washington: AOAC Inc.

Aliya, L., Rahmi, Y., \& Soeharto, S. (2016). Mi "Mocafle" peningkatan kadar gizi mie kering berbasis pangan lokal fungsional. Indonesian Journal of Human Nutrition, 3(1), 32-41. Retrieved from kalteng.litbang.pertanian.go.id

Aller, E. E. J. G., Abete, I., Astrup, A., Martinez, J. A., \& Baak, M. A. Van. (2011). Starches, sugars and obesity. Nutrients, 3, 341-369. doi: 10.3390/nu3030341

Anadón, A., Martínez-larrañaga, M. R., Ares, I., \& Martínez, M. A. (2016). Proboitics: savety and toxicity consideration. Nutraceuticals. 777-798. doi: 10.1016/B978-0-12-802147-7.00054-1

Arora, B., Kamal, S., \& Sharma, V. P. (2018). Nutritional and quality characteristics of instant noodles supplemented with oyster mushroom (P. ostreatus). Journal of Food Processing and Preservation, 42(2), 1-8. doi: 10.1111/ jfpp. 13521

Ashwar, B. A., Gani, A., Wani, I. A., Shah, A., Masoodi, F. A., \& Saxena, D. C. (2016). Production of resistant starch from rice by dual autoclaving-retrogradation treatment: Invitro digestibility, thermal and structural characterization. Food Hydrocolloids, 56, 108-117. doi: 10.1016/j.foodhyd.2015.12.004

Astawan, M. (2011). Pangan fungsional untuk kesehatan yang optimal. Bogor: Fakultas Teknologi Pertanian IPB.

Badan Standardisasi Nasional. (2012). SNI 3551:2012 Mi Instan. Jakarta: Badan Standarisasi Nasional.

Behall, K. M., Scholfield, D. J., Hallfrisch, J. G., \& Liljeberg-elmståhl, H. G. M. (2006). Consumption of both resistant starch and $\beta$-glucan improves postprandial plasma glucose and insulin in women. Diabetes Care, 29(5), 976-981. doi: 10.2337/dc05-2012

Colyer, C. G. B., Landon, S., \& Salman, H. (2013). The Resistant Starch Report. food australia supplement, 1, 11-13. Retrieved from http:// foodaust.com.au/wp-content/uploads/2012/09/ starch_supplement.pdf

Du, S. K., Jiang, H., Ai, Y., \& Jane, J. L. (2014). Physicochemical properties and digestibility of common bean (Phaseolus vulgaris L.) starches. Carbohydrate Polymers, 108(1), 200-205. doi: 10.1016/j.carbpol.2014.03.004

Dubois, M., Gilles, K. ., Hamilton, J. ., Rebers, P. ., \& Smith, F. (1956). Calorimetric method for determination of sugars and related substances. Journal Analytical Chemisrty, 28, 350-356. doi: 10.1021/ac60111a017

Dupuis, J. H., Liu, Q., \& Yada, R. Y. (2014). Methodologies for Increasing the Resistant Starch Content of Food Starches: A Review. Comprehensive Reviews in Food Science and Food Safety, 13(6), 1219-1234. doi: 10.1111/1541-4337.12104

Dutson, T. R., \& Orcutt, M. W. (1984). Chemical changes in proteins produced by thermal processing. Journal of Chemical Education, 61(4), 303-308. doi: 10.1021/ed061p303

European Food Safety Authority. (2014). Scientific Opinion on the safety and efficacy of tannic acid when used as feed flavouring for all animal species. EFSA Journal, 12(10), 3828. doi: 10.2903/j.efsa.2014.3828

Foster-Powell, K., \& Miller, J. B. (1995). International tables of glycemic index. The American Journal of Clinical Nutrition, 62(4), 871S-890S. doi: 10.1093/ajen/62.4.869

Gillatt, P. (2001). 12 - Flavour and aroma development in frying and fried food. Hertfordshire: Woodhead Publishing Series in Food Science, Technology and Nutrition. 266-336. doi: 10.1533/9781855736429.3.266

Herningtyas, E. H., \& Ng, T. S. (2019). Prevalence and distribution of metabolic syndrome and its components among provinces and ethnic groups in Indonesia. BMC Public Health, 19(1), 1-12. doi: 10.1186/s12889-019-6711-7

Hou, G. (Ed.). (2010). Asian Noodles: Science, Technology, and Processing. Hoboken, NJ, USA: John Wiley \& Sons, Inc.

Huh, I.S., Kim, H., Jo, H.K., Lim, C.S., Kim, J.S., Kim, S.J., ... Chang, N. (2017). Instant noodle consumption is associated with cardiometabolic 
risk factors among college students in Seoul. Nutrition Research and Practice, 11(3), 232239. doi: $10.4162 / \mathrm{nrp} .2017 .11 .3 .232$

Huma, N., Anjum, F. M., Sehar, S., Issa Khan, M., \& Hussain, S. (2008). Effect of soaking and cooking on nutritional quality and safety of legumes. Nutrition and Food Science, 38(6), 570-577. doi: /10.1108/00346650810920187

Jiménez, N., Bohuon, P., Lima, J., Dornier, M., Vaillant, F., \& Pérez, A. M. (2010). Kinetics of anthocyanin degradation and browning in reconstituted blackberry juice treated at high temperatures (100-180 $\left.{ }^{\circ} \mathrm{C}\right)$. Journal of Agricultural and Food Chemistry, 58(4), 2314-2322. doi: 10.1021/jf902381e

Karamać, M. (2009). Chelation of $\mathrm{Cu}(\mathrm{II}), \mathrm{Zn}(\mathrm{II})$, and $\mathrm{Fe}$ (II) by tannin constituents of selected edible nuts. International Journal of Molecular Sciences, 10(12), 5485-5497. doi: 10.3390/ ijms10125485

Kaur, B., Ariffin, F., Bhat, R., \& Karim, A. (2012). Progress in starch modification in the last decade. Food Hydrocolloids, 26, 398-404. doi: 10.1016/ j.foodhyd.2011.02.016

Kementerian Kesehatan Republik Indonesia. (2013). Riset Kesehatan Dasar 2013. Jakarta: Badan Penelitian dan Pengembangan Kesehatan Kementerian Kesehatan RI

Kementerian Kesehatan Republik Indonesia.. (2018). Hasil Utama Riskesdas 2018 Provinsi Jawa Timur. Jakarta : Badan Penelitian dan Pengembangan Kesehatan Kementerian Kesehatan RI

Kim, M. J., Shin, S. N., \& Kim, S. K. (2000). Proximate composition and calorie of korean instant noodles. Korean Journal Food Science Technology, 32(5), 1043-1050. Retrieved from http://www.koreascience.or.kr/article/ JAKO200003042121497.page

Kumar, S., Verma, A. K., Das, M., Jain, S. K., \& Dwivedi, P. D. (2013). Clinical complications of kidney bean (Phaseolus vulgaris L.) consumption. Nutrition, 29(6), 821-827. doi: 10.1016/j.nut.2012.11.010

Manonmani, D., Bhol, S., \& Bosco, S. J. D. (2014). Effect of red kidney bean (Phaseolus vulgaris L.) flour on bread quality. OALib, 01(01), 1-6. doi: 10.4236/oalib.1100366

Margier M, Georgé S, Hafnaoui N, Remond D, Nowicki M, Du Chaffaut L, Amiot M-J, Reboul E. (2018). Nutritional composition and bioactive content of legumes: Characterization of pulses frequently consumed in France and effect of the cooking method. Nutrients, 10(11), 1-12. doi: 10.3390/nu10111668

Meilgaard, M. C. (2015). Sensory Evaluation Techniques, Fifth Edition. Boca Raton: CRC Press. doi: 10.1201/b19493

Moore, D. R., Robinson, M. J., Fry, J. L., Tang, J. E., Glover, E. I., Wilkinson, S. B., Prior, T., Tarnopolsky, M. A., Phillips, S. M. (2009). Ingested protein dose response of muscle and albumin protein synthesis after resistance exercise in young men. American Journal of Clinical Nutrition, 89(1), 161-168. doi: 10.3945/ajcn.2008.26401

Nakthong, N., Wongsagonsup, R., \& Amornsakchai, T. (2017). Characteristics and potential utilizations of starch from pineapple stem waste. Industrial Crops and Products, 105, 74-82. doi: 10.1016/j.indcrop.2017.04.048

Noda, T., Tsuda, S., Mori, M., Takigawa, S., Matsuura-Endo, C., Kim, S.-J., Hashimoto, N. and Yamauchi, H.. (2006). Effect of potato starch properties on instant noodle quality in wheat flour and potato starch blends. Starch/Staerke, 58(1), 18-24. doi: 10.1002/star.200500439

Nurcahyo, T. A. (2011). Pola makan mie instan: studi antropologi gizi pada mahasiswa antropologi Fisip Unair. Jurnal Antropologi Gizi, (1), 1-14. Retrieved from http://web.unair.ac.id/admin/ file/f_34835_31mie.pdf

Office of the Gene Technology Regulator. (2003). The biology \& ecology of pineapple in Australia. Health Department of Australia. Retrieved from http://www.ogtr.gov.au/internet/ogtr/publishing. nsf/content/pineapple-3/\$FILE/pineapple.pdf

Olanipekun, O. T., Omenna, E. C., Olapade, O. A., Suleiman, P., \& Omodora, O. G. (2015). Effect of boiling and roasting on the nutrient compostion of kidney beans seed flour. Sky Journal of Food Science, 4(2), 024-029. Retrieved from http:// www.skyjournals.org/SJFS

Olorunsogo, S. T., Adebayo, S. E., Orhevba, B. A., \& Awoyinka, T. B. (2019). Physicochemical properties of instant noodles produced from blends of sweet potato, soybean and corn flour. Food Research, 3(5), 391-399. doi: 10.26656/ fr.2017.3(5).304

Paddon-jones, D., Westman, E., Mattes, R. D., Wolfe, R. R., \& Astrup, A. (2008). Protein, weight management, and satiety $1-4$. The American Journal of Clinical Nutrition, 87(5), 1558-1561. doi: 10.1093/ajen/87.5.1558S

Pangastuti, H. A., Affandi, D. R., \& Ishartani, D. (2013). Karakterisasi sifat kimia tepung kacang 
lawa merah (Phaseolus Vulgaris L.) Dengan beberapa perlakuan pendahuluan. Agritekno, Jurnal Teknologi Pertanian, 2(1), 20-29.

Park, J., Lee, J. S., Jang, Y. A., Chung, H. R., \& Kim, J. (2011). A comparison of food and nutrient intake between instant noodle consumers and non-instant noodle consumers in Korean adults. Nutrition Research and Practice, 5(5), 443-449. doi: 10.4162/nrp.2011.5.5.443

Pato, U., Yusuf, Y., Isnaini, R. F., \& Dira, D. M. (2019). The Quality of Instant Noodle Made from Local Corn Flour and Tapioca Flour. Journal of Advanced Agricultural Technologies, 3(2), 118-123. doi: 10.18178/joaat.3.2.118123

Pusat Data dan Sistem Informasi Pertanian. (2016). Outlook Komoditas Pertanian Sub Sektor Hortikultura Nenas. Jakarta: Sekertariat Jendral Kementerian Pertanian. Retrieved from http:// epublikasi.setjen.pertanian.go.id/epublikasi/ outlook/2016/Hortikultura/OUTLOOK NENAS 2016/files/assets/common/downloads/ OUTLOOK NENAS 2016.pdf

Rosida, D. R. (2012). Mie Dari Tepung Komposit (Terigu, Gembili (Dioscorea Esculenta), Labu Kuning) dan Penambahan Telur. Rekapangan, 6(1), 32-37. Retrieved from ejournal.upnjatim. ac.id/index.php/rekapangan/article/view/419

Sasanam, S., Paseephol, T., \& Moongngarm, A. (2011). Comparison of Proximate Compositions , Resistant Starch Content, and Pasting Properties of Different. Nutrition and Food Engineering, 5(9), 553-557. doi: 10.5281/ zenodo.1081571

Shamai, K., Bianco-Peled, H., \& Shimoni, E. (2003). Polymorphism of resistant starch type III. Carbohydrate Polymers, 54, 363-369. doi: 10.1016/S0144-8617(03)00192-9

Shin, H. J., Cho, E., Lee, H.-J., Fung, T. T., Rimm, E., Rosner, B., ... Hu, F. B. (2014). Instant noodle intake and dietary patterns are associated with distinct cardiometabolic risk factors in Korea. The Journal of Nutrition, 144(8), 12471255. doi: $10.3945 /$ jn.113.188441
Singh, B., Singh, J. P., Shevkani, K., Singh, N., \& Kaur, A. (2017). Bioactive constituents in pulses and their health benefits. Journal of Food Science and Technology, 54(4), 858-870. doi: /10.1007/s13197-016-2391-9

Sirichokworrakit, S., Phetkhut, J., \& Khommoon, A. (2015). Effect of Partial Substitution of Wheat Flour With Riceberry Flour on Quality of Noodles. Procedia - Social and Behavioral Sciences, 197(February), 1006-1012. doi: 10.1016/j.sbspro.2015.07.294

Symons, T. B., Sheffield-Moore, M., Wolfe, R. R., \& Paddon-Jones, D. (2009). A moderate serving of high-quality protein maximally stimulates skeletal muscle protein synthesis in young and elderly subjects. Journal of the American Dietetic Association, 109(9), 1582-1586. doi: 10.1016/j.jada.2009.06.369

Teodorowicz, M., Van Neerven, J., \& Savelkoul, H. (2017). Food processing: The influence of the maillard reaction on immunogenicity and allergenicity of food proteins. Nutrients, 9(8), 1-18. doi: $10.3390 /$ nu 9080835

WINA. (2019). Global Demand for Instant Noodles. Retrieved from https://instantnoodles.org/en/ noodles/market.html

World Health Organization. (2018). NCDs Country Profiles 2018. Retrieved from https://www.who. int/nmh/publications/ncd-profiles-2018/en/

Wulan, S. N., Saparianti, E., Widjanarko, S. B., \& Kurnaeni, N. (2006). Simple starch modification using physical, chemical and combined physical phy sical and chemical methods to produce pre - cooked flour rich in resistant starch made of corn , potato and cassava. Jurnal Teknologi Pertanian, 7(1), 1-9. Retreived from https://jtp. ub.ac.id/index.php/jtp/article/view/209/586

Yin, W., Hewson, L., Linforth, R., Taylor, M., \& Fisk, I. D. (2017). Effects of aroma and taste, independently or in combination, on appetite sensation and subsequent food intake. Appetite, 114, 265-274. doi: 10.1016/j. appet.2017.04.005 